\title{
Wise Water Resources Management under the Increasing Number of Refugees in the Third Poorest Water Resources Country (Jordan) - A Suggested Future Spatial Plan for Water Resources Investments
}

\author{
Taleb Odeh ${ }^{*}$, Alsharifa H. Mohammad ${ }^{2}$ \\ ${ }^{1}$ Department of Natural Resources in Arid Lands, The Hashemite University, Prince Al Hassan Bin Talal Faculty of Arid \\ Lands, Zarqa 13133, Jordan \\ ${ }^{2}$ Water, Energy and Environment Center, the University of Jordan, Amman 11942, Jordan
}

Corresponding Author Email: talebs@ hu.edu.jo

https://doi.org/10.18280/ijsdp.150214

Received: 23 October 2019

Accepted: 8 February 2020

\section{Keywords:}

groundwater, surface water, sustainable water resources management, spatial plan

\begin{abstract}
Jordan is the 3rd poorest country in water resources worldwide. It is mostly arid land with limited water resources. It has a high population growth rate and recently receives increasable number of Syrian refugees. Therefore, a wise management of water resources have a great importance in order to keep a life for the people. However, water resources in Jordan are mainly from the groundwater of unconfined limestone aquifer and confined sandstone. The groundwater levels of these two aquifers are rapidly decreasing as results of groundwater over pumping. The groundwater over pumping causes groundwater quality deterioration. Therefore, it is not only the water quantity issues that is facing the country but also the water quality problem. However, Jordan is trying to address the challenge of limited water resources and groundwater over pumping according to several water resources developments projects such as dams, water harvesting, desalination and cloud seeding. This paper suggests an optimized spatial plan for these projects according to Geographic Information Systems (GIS) in order to increase its efficiency.
\end{abstract}

\section{INTRODUCTION}

Arid regions countries suffer from water shortage as a result of the limitation of surface and ground water resources [1]. However, they have usually average rainfall of less than 100 $\mathrm{mm}$ per year and high amount of evaporation that decreases the water availability. Jordan is among of these arid countries that has a rapid increase in population as a result of population growth and war migrations [2, 3].

Jordan has limited water resources and the increased in inhabitants that generate a water crisis. It is actually classified as the third poorest water resources country world wild [4]. Therefore, there must be a sustainable water resources in order to maintain water supplying for the next generations [2-5].

Several water resources projects in Jordan were completed in the last two decades in order to keep the water resources sufficient and in a good quality for the different water usages. These projects mainly include dams, water harvesting and saline water desalinisation. The mentioned project succeeded to reduce the water demanding pressure on natural water resources $[3,5]$.

However, the efficiency of these projects could be increased if there was a spatial plan in order to find the optimized sites in term of economical and environmental values [5]. Therefore, the objective of this research is to carry out a spatial plan for further water resources projects in Jordan with consideration for economical and environmental values. Geographic Information Systems (GIS) is a useful tool in order to undertake spatial analysis and present any spatial map. Therefore, we used it to carry out our mapping [6].

\section{BACKGROUND}

Jordan is located in Middle East between Syria, Iraq, Saudi Aribia and west bank. It has an area of about $89000 \mathrm{Km}^{2}$ that has arid and semi arid climatic conditions [3] (Figure 1).

However, the elevations above sea level varies extremely in Jordan. For instance, at Dead Sea shore line the elevation is about - 420 meter below the sea level in the south west mountains the elevations reach to more than 1800 meter above the sea level [3]. The differences in these elevations changed relatively in a short distance not more than few tens kilometer in most of the times therefore Jordan is classified as high relief topography area [2]. Geomorphologically, the high land area generated the mountains while the low land generated plateau areas. The drainage network runs directionally from the mountains to the plateau areas through small and large Wadis $[2,3]$.

The high relief topography of Jordan controls its landscape typology. It was generated mainly by regional geological structures so called Dead Sea Transform (DST) fault and local structures such as Ajloun domes [4]. Accordingly, landscape units in Jordan are correlated with the geology too. However, the topography in Jordan created its climatic zones (Figure 2) with different hydrologic landscape units [4]. North west and middle west of Jordan have the highest amount of rainfall up $500 \mathrm{~mm} /$ year where the major surface and ground water resources are available [3].

Jordan has one of the highest population growths worldwide that is about $3.6 \%$ per year. However, during the last 50 years Jordan received many numbers of refugees from Palestine, 
Iraq and Syria as a result of war and civil war in these countries. The high population growth and increased number of refugees lead to increase inhabitant of Jordan rapidly [2].

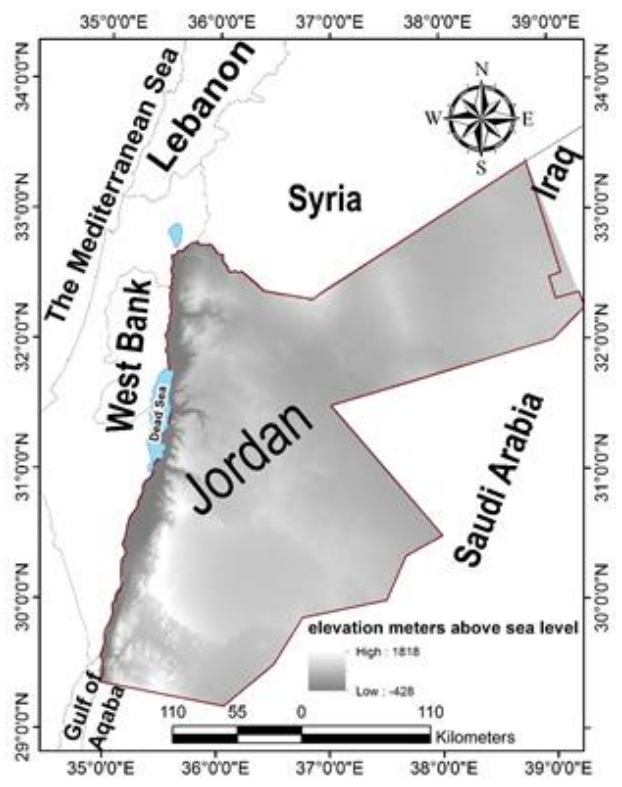

Figure 1. Map of Jordan location

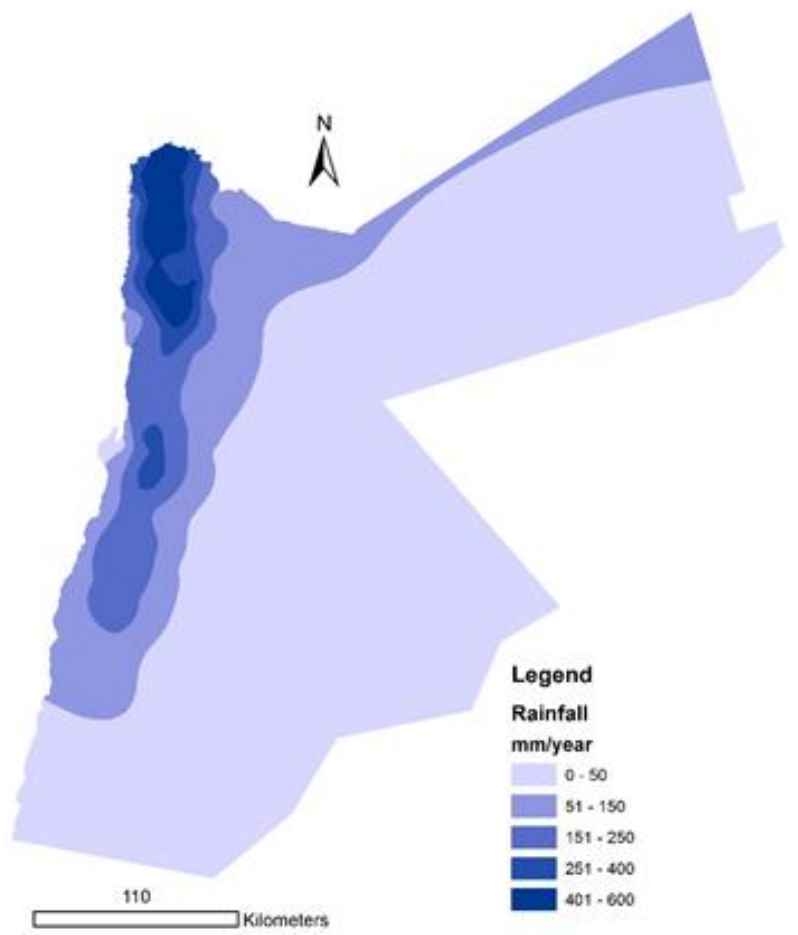

Figure 2. Rainfall patterns map of Jordan

According to the Ministry of Water and Irrigation data base most of Jordan receives rainfall quantity of less than $50 \mathrm{~mm}$ per year $[1,3]$. The arid climatic conditions, limited water resources and the increased population are generating a serious water crisis in Jordan [2, 3]. However, Jordan try to manage that crisis through alternative artificial water resources such rain water harvesting and sea water desalination. These projects need a spatial plan that specify where is the optimized location for them. This plan has been not carried out in Jordan.

Jordan has 15 major surface water catchment areas (Figure 3 ) and 12 major groundwater basins (Figure 4) as resources for fresh.

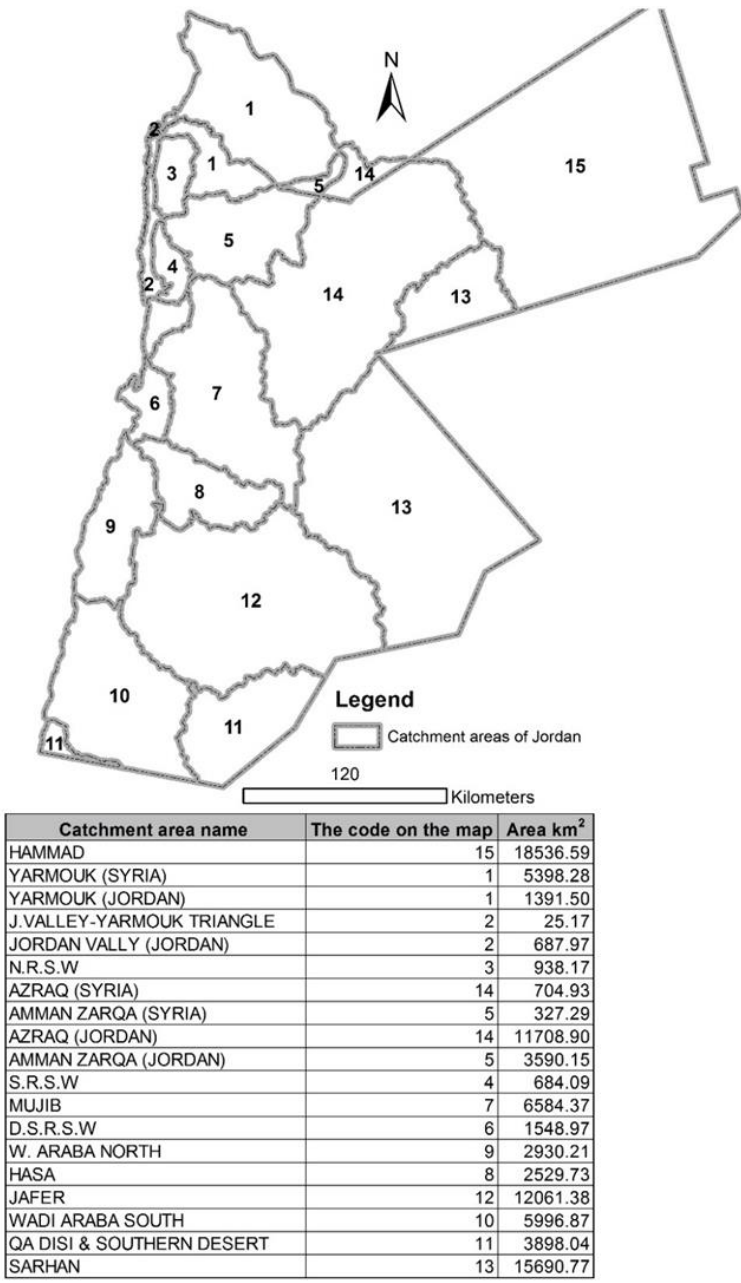

Figure 3. Catchment areas of Jordan

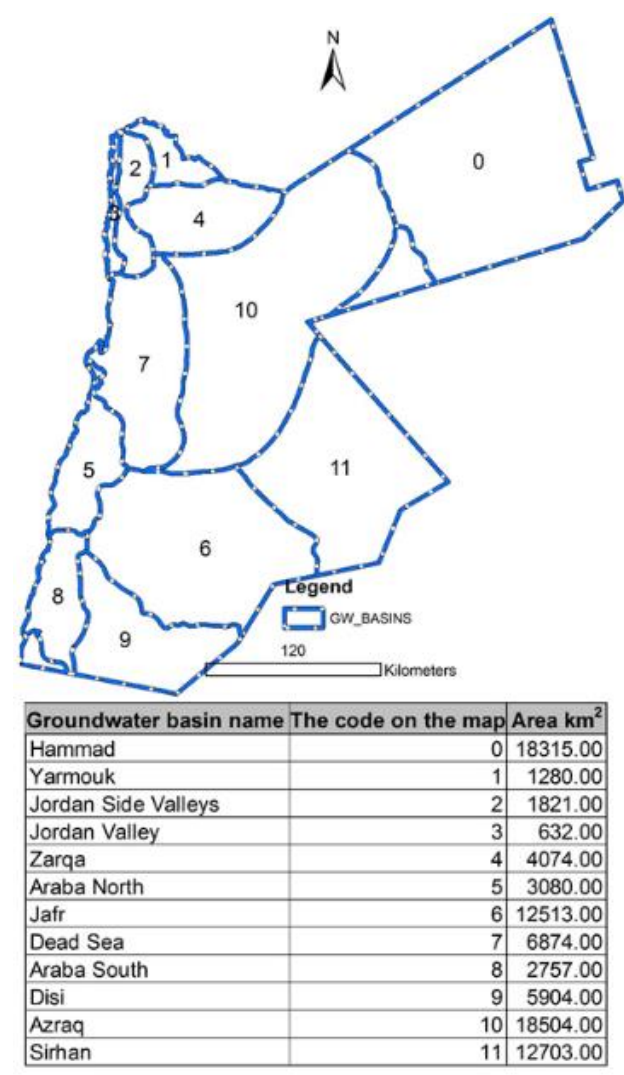

Figure 4. Groundwater basins of Jordan 
More than $50 \%$ of water usages in Jordan are mainly pumped from the groundwater. However, groundwater is the main resource for domestic fresh water in Jordan. It is available in two main aquifers: upper unconfined unsaturated limestone aquifer and confined sand stone aquifer. The safe yield of renewable groundwater of the upper aquifer is about $275 \mathrm{MCM} / \mathrm{y}$ [7]. The surface water resources in Jordan have a water quality degradation while the groundwater resources have over pumping and water quality degradation too [3]. The aimed spatial plane that would carry out have to consider the distribution of the groundwater basins and surface water catchment area.

\section{DATA AND METHODS}

Geographic Information Systems (GIS) is a useful tool to integrate and analyze the spatial data of water resources and its large data disciplines. It carries out the maps of spatial analysis rapidly and professionally too [8-11]. Therefore, we used GIS in order to analyze the mega geodata base that Ministry of Water and Irrigation (MWI) in Jordan has about the water resources [12]. However, ArcGIS 10.2 as a software for GIS was used to store and analyse data since it has practical tools for manipulating, analyzing and simulating water resources data $[8,13]$. Figure 5 shows the mechanism that we used in order to achieve our results. However, retrieving, labelling and manipulating were used as GIS techniques in order to achieve our spatial analysis.

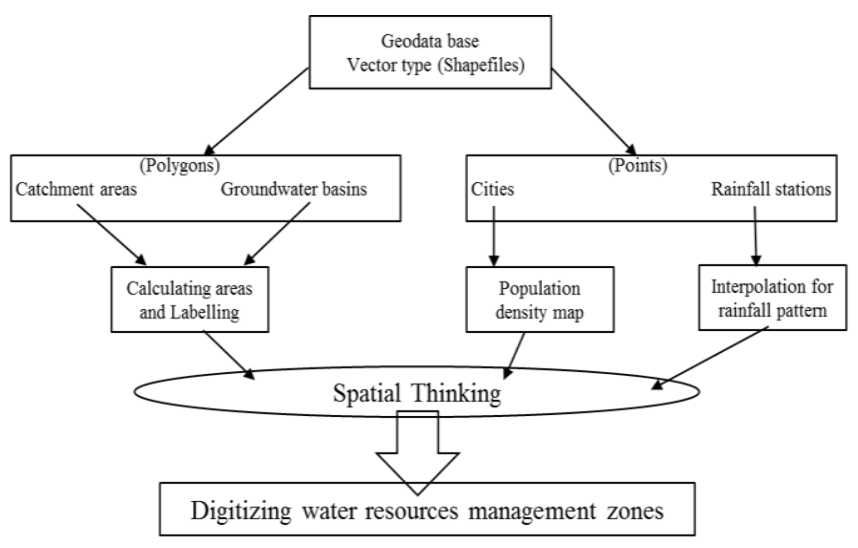

Figure 5. Flow chart for generating water resources management zones

\section{RESULTS AND DISCUSSION}

Jordan has twelve governorates which each one has either an independent or share water resources with other governorate [2] (Figure 6). Jordan has two major usages for water: 1) industrial and municipal usage that consumes about $28 \%$ of the total usage and 2) Irrigation for the agriculture activity consumes about $72 \%$ of the total water usage $[2,3]$. However, the total amount of the consumed water is rapidly increasing as a result of the 1) water drinking demand for the increased number of inhabitants and 2) water usages demand for industrial, agricultural and urban activities [2].

Jordan face the rapid water demanding by pumping more surface and groundwater. A major challenge is the groundwater over-pumping since the groundwater abstraction is more than the groundwater recharge $[1,2,8]$ that effects the groundwater quality negatively.

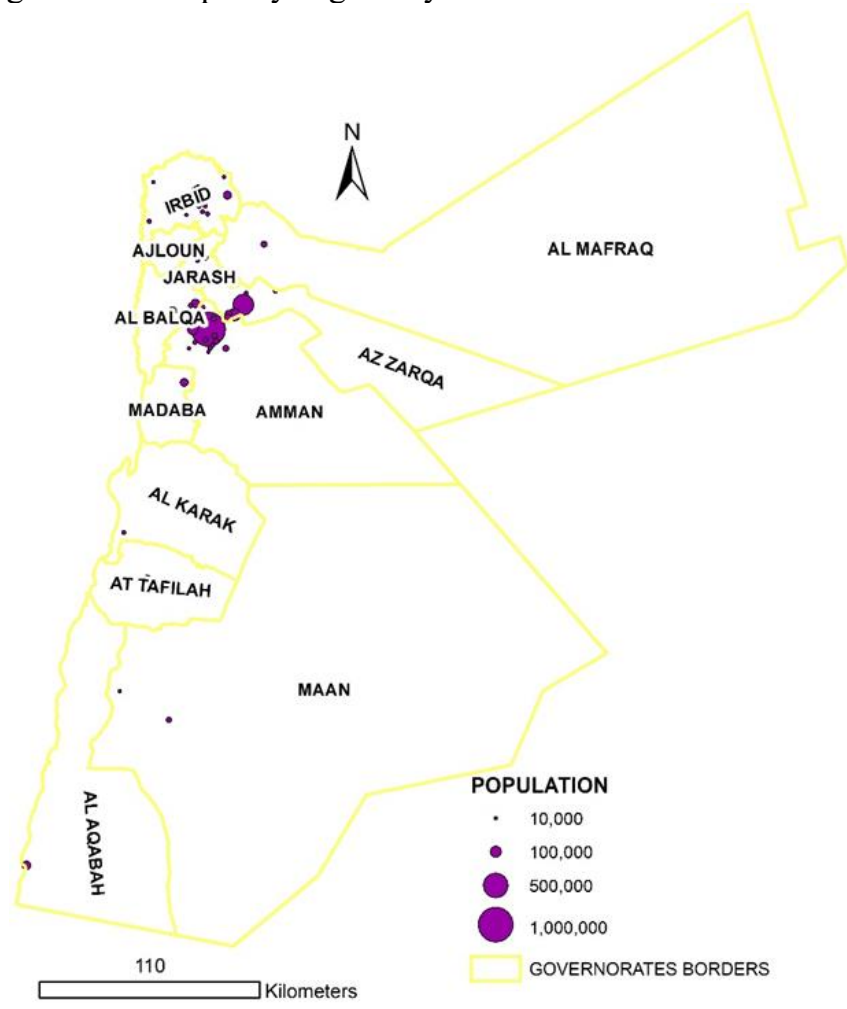

Figure 6. Population density of Jordan

Currently, the total average renewable groundwater pumping is about $391 \mathrm{MCM} /$ year which is more than the average safe yield of groundwater (274 MCM/year) [2]. Water resources management and planning has a large extent of spatial data. These data include both water quantity and quality. However, a wise sustainable water projects in Jordan were carried out in order to enhance sustainable water resources management. These projects are:

1) The Red Sea-Dead Sea Conduit (Canal) project: it will connect the Dead Sea with the Red Sea at The Gulf of Aqaba. However, fresh water would be produced by using the energy of the elevation differences between the Dead and the Red Seas. Jordan would have about $300 \mathrm{MCM} /$ year by this project [12]. The aimed project would pump water from the Red Sea to the level of about 230 meters above sea level within the gulf of Aqaba $[2,12]$. Then the sea water would move within Wadi Arabah by the force of gravity through especial pipes to the Dead Sea Lake that has an elevation of -420 meter below the sea level. However, the Red Sea-Dead Sea Canal would utilize about $220 \mathrm{~km}$ of pipes for sea and brine water, parallel to the Arabah Wadi in Jordan [2, 6, 12]. It would also have about 170 $\mathrm{km}$ of freshwater pipes to the capital of Jordan Amman. The project would have along with the pipelines water desalination and hydroelectric plants [12].

2) The Disi water conveyance project: The groundwater in the Disi confined aquifer was generated since about 30,000 years ago in the Pleistocene era. It is a regional aquifer between Jordan and Saudi Arabia and has about 319 kilometers long and consists of sandstone 500 meters below of the land surface. The groundwater of the Disi aquifer is fossil groundwater. However, the aquifer is recharged by about $50,000,000 \mathrm{~m}^{3}$ of water per year. It pumps about 100 $\mathrm{MCM} /$ year from the Disi aquifer in south of Jordan. The distance of the project pipes is about $325 \mathrm{~km} \mathrm{[2,} \mathrm{3,} \mathrm{10,} \mathrm{13].}$

3) Water desalination and nuclear plant project: Jordan 
would establish a nuclear plant to use the phosphate ore deposit that it has. However, the energy that would be produce it would be use to desalinate the sea water of Aqaba gulf $[2,3$, 10]. The idea is still under studying since there is still environmental conservation about the nuclear usages risks.

4) Rain water harvesting projects: these types of project covered mostly east of Jordan. Although it was used since long time but it still the quantity of water that is collected is limited. North and Middle West of Jordan receive the highest amount of rainfall up $500 \mathrm{~mm} / \mathrm{yr}$ therefore this region would be the optimized region for water harvesting. However, currently most of the water harvesting are in the east of Jordan where is the minimum amount of rainfall [14] which we think that the government of Jordan has to rethink about that.

According to the previous water resources projects Jordan could be divided into 4 water resources zones that are presented in Figure 7. However, this map is preliminary and has to be improved according to the dynamic results of the sustainable water resources management in Jordan [14-16].

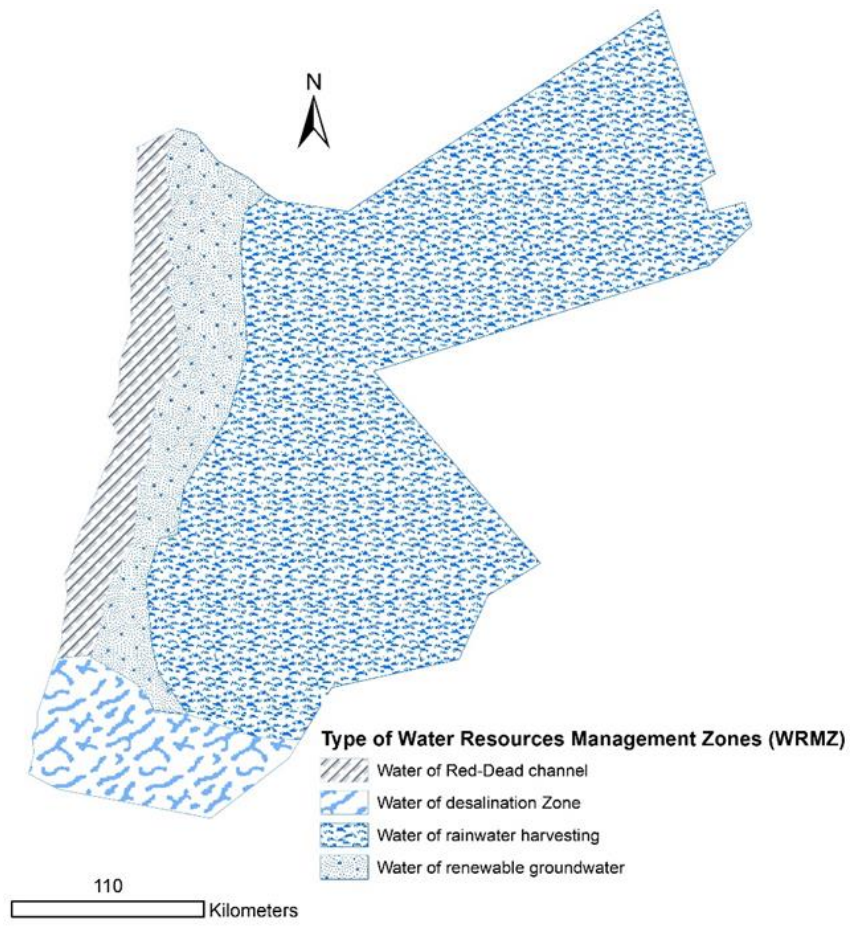

Figure 7. A suggested water resources plan for Jordan

\section{CONCLUSIONS}

Jordan carried out integrated sustainable projects for water resource management in order to face the water demands of increased native population and migrated refugees. The water demand in Jordan is increased because of the rapid urban development too especially in city of Amman, Zarqa and Irbid. However, Jordan still need to extend other water projects that would help to have sustainable water resources management such as: water harvesting, cloud seeding, Dams construction and River restoration. However, GIS is an optimized tool for spatial analysis in order to generate water management zones.

\section{ACKNOWLEDGMENT}

The authors are grateful to The Hashemite University for supporting this research.

\section{REFERENCES}

[1] AL-Eisawi, D. (1996). Vegetation of Jordan. UNESCO, Cairo Office, pp. 29-43.

[2] Department of Statistics. (2016). Statistical Yearbook. Jordan, $200 \mathrm{p}$.

[3] Salameh, E., Bannayan, H. (1993). Water Resources of Jordan-Present Status and Future Potentials. Friedrich Ebert Stiftung, Amman.

[4] Odeh, T., Boulad, N., Abed, O., Abu Yahya, A., Khries, N., Abu-Jaber, N. (2017). The influence of Geology on landscape typology in Jordan: Theoretical understanding and planning implications. https://doi.org/10.3390/land6030051

[5] Winter, T.C. (2001). The concept of hydrologic landscapes. Journal of the American Water Resources Association, 37(2): 335-349. https://doi.org/10.1111/j.1752-1688.2001.tb00973.x

[6] Food and Agriculture Organization of the United Nations (FAO). (2011). The State of the World's Land and Water Resources for Food and Agriculture. Earthscan 711 Third Avenue, NY 10017, New York.

[7] Alley, W.M., Reilly, T.E., Franke, O.L. (1999). Sustainability of Ground-Water Resources. U.S. Geological Survey Circular 1186, p. 79.

[8] Jaiswal, RK., Mukherjee, S., Krishnamurthy, J., Saxena, R. (2003). Role of remote sensing and GIS techniques for generation of groundwater prospect zones towards rural development - an approach. Int. J. Remote Sens., 24(5): 993-1008. https://doi.org/10.1080/01431160210144543

[9] Berndtsson, R., Larson, M. (1987). Spatial variability of infiltration in a semi-arid environment. J. Hy-drol., 90: 117-133. https://doi.org/10.1016/0022-1694(87)90175-2

[10] Changnon, S.A., Huff, F.A., Hsu, C.F. (1988). Relations between precipitation and shallow ground-water in Illinois. Journal of Climate, 1: 1239-1250. https://doi.org/10.1175/1520-0442(1988)

[11] De Vries, J.J., Simmers, I. (2002). Groundwater recharge: An overview of processes and challenges. Hydrogeology Journal, 10: 5-17. https://doi.org/10.1007/s10040-0010171-7

[12] Ministry of Water Resources and Irrigation in Jordan 2019. Open Online Data File.

[13] Margane, A. (2015). Updating the Groundwater Contour Map of the A7/B2 Aquifer in North Jordan. Technical Report BGR.

[14] Ministry of Agriculture, Jordan. (1994). National Soil Map and Land Use Project - The Soils of Jordan, Level 2: Semi-detailed Studies, vol. 2. Main Report, Ministry of Agriculture, Jordan.

[15] Odeh, T., Rödiger, T., Geyer, S., Schirmer, M. (2014). Hydrological modelling of a heterogeneous catchment using an integrated approach of remote sensing, a geographic information system and hydrologic response units: The case study of Wadi Zerka Ma'in catchment area, north east of the Dead Sea. Environ Earth Sci. https://doi.org/10.1007/s12665-014-3627-5

[16] Scheffran, J., Brauch, H.G. (2014). Conflicts and security risks of climate change in the Mediterranean region, in The Mediterranean Sea, edited, pp. 625-640, Springer. https://doi.org/10.1007/978-94-007-6704-1_39 